\title{
Szakcikk
}

\section{Visegrádi Négyek környezetgazdálkodásának és fenntartható mezőgazdaságának elemzése}

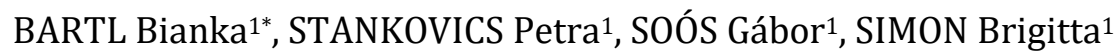

${ }^{1}$ Magyar Agrár- és Élettudományi Egyetem, Georgikon Campus, 8360 Keszthely, Festetics György út 7.

\section{ABSTRACT - Analysis of the sustainable agriculture and environmental management of the Visegrád Group \\ (Article)}

Author: Bianka BARTL ${ }^{1}$, Petra STANKOVICS ${ }^{1}$, Gábor SOÓS ${ }^{1}$, Brigitta SIMON ${ }^{1}$

Affiliation: ${ }^{1}$ Hungarian University of Agriculture and Life Sciences, Georgikon Campus, 8360 Keszthely, Festetics Gy. 7. Hungary

In our study, we analyze the commitments of the Visegrad Four National Energy and Climate Plans (NECPs) for the period 2021-2030 within the European Union environment policy, with special regard to the Land Use, LandUse Change and Forestry (LULUCF) sector. Based on our research, it can be said that the willingness of countries to contribute to the achievement of EU goals has low or modest ambition. Within the framework of the NECP, there are significant differences between the Visegrad Four's implementation plans for LULUCF. In connection with forest management, the emphasis in the Czech Republic for the next few years will be on afforestation, while in the case of Hungary, increasing logging production will be emphasized. In addition, Slovakia has presented a plan of an outstanding amount for draft carbon sequestration by forest. In the case of Poland, a mandatory carbon sequestration rate was provided in the forest management plan.

Keywords: NECP, LULUCF, environment policy, emissions trading scheme - ETS

\section{BEVEZETÉS}

A Visegrádi Négyek (V4) 2004-es csatlakozásuk óta az Unió által meghatározott környezetpolitikai szabályozások alá tartoznak. A csatlakozást követően több feladat és kötelezettség nehezedik az országcsoportra. Az Unió környezetvédelmi előírásai az egyik legszigorúbb szabályozások közé tartoznak. Az EU a környezetpolitikáját úgy alakították ki, hogy támogassa a gazdaságok zöldülését, emellett az egészség és jóllét, valamint a természeti erőforrások védelme is megvalósuljon. A kialakított jogszabályok célja a természetes élőhelyek védelme, tiszta levegő-és víz biztosítása, hulladékok megfelelő kezelése, mérgező és vegyi anyagokkal kapcsolatos ismeretek bővítése és a gazdaságok fenntarthatóság irányába való állítása (Európai, 2014) 
Az EU környezetvédelmi politikája az Európai Unió működéséről szóló szerződés 11. és 191-193. cikkein alapul. A Szerződés 191. cikke szerint az éghajlatváltozás elleni küzdelem az EU környezetvédelmi politikájának egyik kifejezett célja (Az Európai Unió Működéséről szóló Szerződés Egységes Szerkezetbe Foglalt Változata, 2012.).

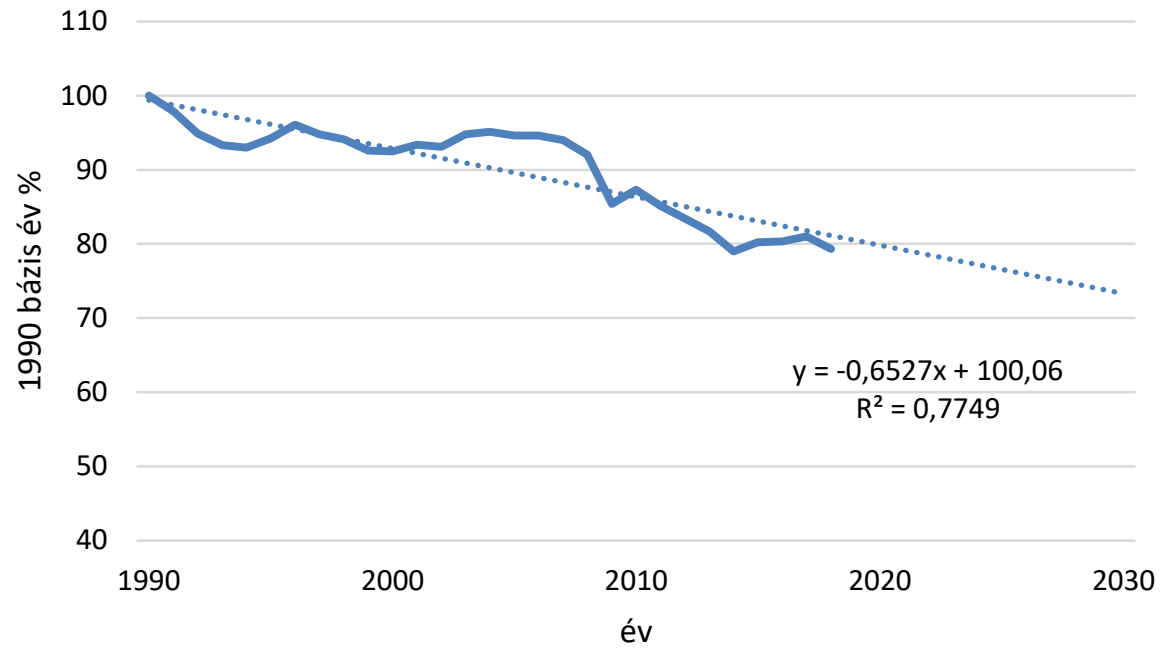

\section{1. ábra}

Az EU 27 ÜHG kibocsátásának alakulása 1990 bázis év mellett, valamint annak előre jelzése trendvonal segítségével Forrás: (EUROSTAT., 2021)sajátszerkesztés

Magyarázat: EU-27-et mutattuk ki az ábrán mert Nagy-Britannia kilépet az Unióból 2020-ban (Figure 1. EU 27 GHG emission in 1990 base year, and its forecast using a trend line. Explanation: We have shown EU-27 in the figure because Great-Britain have left the EU in 2020)

Az éghajlatváltozás elleni küzdelem érdekében, az Unió kialakította az Európai Zöld Megállapodást, amelyben következő kötelezettségeket határozza meg:

- üvegházhatású-gáz (ÜHG) kibocsátások min 40\%-os csökkentése, EU Kibocsátási Kereskedelmi Rendszer (ETS) és az ETS-n kívüli ágazatok kibocsátás-csökkentése 43\%, illetve 30\%, 2005-höz képest (1. ábra);

- energia hatékonyság növelése $32,5 \%$;

- megújuló energia részarányának növelése 32\%-kal, ezek teljesítésére a tagállamoknak 2020 végéig el kellett készíteniük a Nemzeti Energia-és Klíma 
(NECP) tervet. A terv elkészítésének kötelezőségét az energiaunió irányításáról és az éghajlatváltozásról szóló (EU) 2018/1999 európai parlamenti és tanácsi rendelet jelenti (Országgyűlés Hivatala, 2020). (Európai Bizottság, 2019)

Az Európai Zöld Megállapodás keretében az EU tagállamoknak kötelességük a földhasználatból, a földhasználat megváltozásából vagy az erdőgazdálkodásból származó ÜHG kibocsátást úgy alakítani, hogy az legalább megközelítse a légköri $\mathrm{CO}_{2}$ egyenértékű eltávolításával 2021-2030 közötti időszakban. Az Általános Ügyek Tanácsa által 2018. május 14-én elfogadott, a földhasználathoz, földhasználat-változtatáshoz és erdőgazdálkodáshoz kapcsolódó üvegházhatású gáz-kibocsátásra és elnyelésre vonatkozó 2018/841 Földhasználat, földhasználat-változás és erdőgazdálkodás (LULUCF) rendelet támasztja azt a követelményt, hogy minden ágazatnak hozzá kell járulni a 2030-ra vállalt célkitűzésekhez. A Párizsi Megállapodással összhangban készült el, mely szerint a földhasználati szektor különleges szerepet tölt be a klímaváltozás szempontjából. A LULUCF megjelenik a tagállamok által összeállított NECP-ben is. A rendelet kötelező érvényű kötelezettség vállalást határoz meg a tagállamok számára, annak érdekében, hogy a nullszaldós terhelés valósuljon meg. Hatálya kiterjed az erdőkre, valamint mindenféle földhasználatra is. Az új keret lehetőséget biztosít a földhasználat zöldebbé válására, valamint elősegíti az éghajlatintelligens (climate-smart) gyakorlatok kialakulását. A LULUCF-ben az energia szektor által felhasznált biomassza kibocsátást rögzíteni kell, valamint az elszámolását is lehetővé kell tenni a 2030-ra vonatkozó kötelezettségvállalásokkal kapcsolatosan. Ez egy jelentős előre lépés az előző politikához képest, amely ezt a lehetőséget figyelmen kívül hagyta. Az átalakult számviteli szabályok, valamint az erdőgazdálkodás irányításának fejlesztése megalapozza a megújuló energiapolitikát 2020. utáni időszakra. A LULUCF rendelet egyszerüsíti és korszerűsíti az 529/2013 / EU határozat és a Kiotói Jegyzőkönyv szerinti jelenlegi számviteli módszertant. Új keretet hoz létre, a tagállamok számára az erdőgazdálkodásból származó kibocsátás-elnyelés elszámolására, valamint kibővíti a hatályát az összes kezelt földterületre ezzel javítva a számlák alakulását. Az Európai Bizottság (EB) 2020. októberben módosította a LULUCF jogszabályokat. A rendelet bizonyos szintű rugalmasságot enged meg a tagállamok számára. A nettó elszámolt kibocsátás a földhasználatból és erdőgazdálkodásból, illetve az erőfeszítések megosztásáról szóló rendeletből (ESR) származó elkülönítéseket felhasználhatják a nulla terheléses kötelezettség vállalás teljesítésére. Ezen felül adás-vételi piacra bocsáthatják a kötelezettségeiket, ezzel ösztönözve a tagállamokat arra, hogy túlszárnyalják a $\mathrm{CO}_{2}$ eltávolítási kö- 
telezettségüket. A tagállamoknak lehetőségük van úgy növelni $\mathrm{CO}_{2}$ megkötésüket, hogy közben elősegítik a primer szektor megfelelését az ESR-nek ahol a műtrágya és az állatállomány kibocsátását számolják el (Szepesi, 2015).

A tanulmány során célunk a Visegrádi országok NECP terveinek bemutatása, összehasonlítása és értékelése. Emellett külön figyelmet fordítunk a LULUCF szektorra és a tagok ezzel kapcsolatos megvalósítási irányaira. Munkánkban a NECP tervek 5 dimenzióját mutatjuk be, valamint a LULUCF ágazat hozzájárulását emeljük ki a dekarbonizáció területén. Arra keressük a választ, hogy a LULUCF-hez tartozó fakitermelés, valamint falapú biomassza égetése szempontjából milyen lépéseket tesznek az EU és a V4-ek.

\section{ANYAG ÉS MÓDSZER}

A tanulmányunkban a V4-ek által készített terveket mutatjuk be. Kiemelten a LULUCF megjelenését, valamint a célok elérése érdekében az elköteleződésüket vizsgáltuk. Az EB által készített értékelések felhasználásával, valamint a végleges NECP tervek segítségével vizsgáltuk az országok hozzájárulási ambícióit, és a LULUCF-fel kapcsolatos terveiket. Az egyes terveket és értékeléseket az EB hivatalos oldaláról kértük le és tartalom elemzést végeztünk. Az EB értékelése során az EU 2018/1999 rendeletében az 5. cikk és a II. mellékletben foglaltak az irányadók. A rendeletben meghatározott képlet alapján készültek el a felhasznált EB értékelések. A törekvések értékélése során az említett képlet alapján a következő kritériumokat használták fel:

$$
\begin{aligned}
& \mathrm{x} \leq-4 \%=\text { szignifikánsan alacsonyabb } \\
& -4 \%<\mathrm{x} \leq-2 \%=\text { alatt van } \\
& -2 \%<\mathrm{x}<0 \%=\text { valamivel alacsonyabb } \\
& 0 \%=\text { egyenlő } \\
& 0 \%<\mathrm{x}<2 \%=\text { valamivel magasabb } \\
& 2 \% \leq \mathrm{x}<5 \%=\text { felette van } \\
& 5 \% \leq \mathrm{x}=\text { jelentősen meghaladja }
\end{aligned}
$$

(Az x-el a tagállam megújuló energiaforrásokkal kapcsolatos részesedéseire utalva a NECP tervezetében.)

RES képletet: az úgynevezett „ambiciózus rés” kiszámítására használja fel az értékelés. A képlet számítsa során a 2030 prognosztizált átlagos megújuló energia felhasználás bruttó végső értékét kell megadni súlyozva a tagállam 
2030-ra prognosztizált végső energia fogyasztásával és ezt kell megosztani az EU 27-tel.

Az EB értékelésének módszertana alapján az ambíció szintjének meghatározása a következőképpen alakult:

- elegendő, ha a 2030-as nemzeti hozzájárulásban nagyobb az energiacsökkenés, mint az EU szintjén,

- szerény, ha a csökkenés alacsonyabb volt, mint az EU szintjén, de magasabb volt, mint $5 \%$,

- alacsony, ha a csökkenés a 0-5\% tartományban volt, vagy egynél kisebb növekedés volt tapasztalható

- nagyon alacsony, ha mindkét kritérium értéke nő. (European Commission, 2019)

A cikkben megjelenő rövidítések, magyarázata:

ETS- Kibocsátási kereskedelmi rendszer, European Union Emissions Trading System. Az EU kibocsátás-kereskedelmi rendszere (EU ETS) az éghajlatváltozás elleni küzdelemre irányuló uniós politika sarokköve, és kulcsfontosságú eszköze az üvegházhatású gázok kibocsátásának költséghatékony csökkentése érdekében. Ez a világ első nagy szén-dioxid-piaca, és továbbra is a legnagyobb.

ESR- Erőfeszítések megosztása, Effort Sharing Regulation- rendelkezik minden ETS-en kívül eső ágazatról, valamint a LULUCF szektoráról. A rendelet értelmében a tagállamoknak lehetőségük nyílik arra, hogy felhasználjanak korlátozott számú ETS kibocsátási egységet, valamint lehetővé válik, hogy céljaik elérése érdekében a földhasználati ágazatban felhasználjanak korlátozott számú kibocsátás-elnyelést.

\section{EREDMÉNYEK ÉS ÉRTÉKELÉSÜK}

Az ETS az európai közösség elsődleges eszköze a szén-dioxid-kibocsátás csökkentésére. Az ETS az ipar és energia ágazat, valamint 2012 óta a légiközlekedési ágazatokból származó ÜHG kibocsátások csökkentése érdekében jött létre. Ennek 2013-2020 között a 3. szakasza valósult meg, amelyben fix összkvótás rendszert írtak elő. (Az ezt megelőző időszakban nemzet szintű csökkentési követelmény volt az előírás) A 20132020 közötti időszakban évi 1,74\%csökkentésre kötelezte az Európai Unió egészét (2021 után ez évi 2,2\%-ra módosul).

A 3. szakaszban a kibocsátási egységek szétosztása árverés, valamint ingyenes kiosztás révén valósult meg. Az ingyenes kiosztásra a 4-es szakaszban is lehetőség lesz. 
Az intézkedés azokat ágazatokat célozza, amelyek estében jelentős a kibocsátás áthelyezés kockázata (szénszivárgás). A szénszivárgás oka a nagy energiaigényú iparágak fokozatos áttelepítése olyan országokba, ahol kevésbé szigorú kibocsátási határértékek érvényesülnek. Emellett azok az ágazatok, amely esetében alacsony a kibocsát-áthelyezés kockázata, az ingyenes kiosztás mértékének csökkentését tervezik 2026-tól, amely tervezetten 2030-ra 0-ra fog csökkeni. Annak érdekében, hogy a cél megvalósulása megfelelően történjen, fontos nyomonkövetési és tájékoztatási rendszert biztosítani. Az EU 601/2012/ EU rendelete szabályozza a monitorozási rendszert, valamint a 2015/1814 EU határozat rendelkezik működésről, amelyben a tájékoztatásra vonatkozó kritériumok is megjelenik. Ezek lehetővé teszik az ETS kiegyensúlyozott működését. Az ETS hatályán kívül eső ágazatoknak is hozzá kell járulniuk a kibocsátás csökkentéshez, ezekről az ESR rendelkezik. A LULUCF ágazatai, mint ETS-en kívül eső ágazatok, nagy szerepet játszanak az éghajlatváltozással kapcsolatos küzdelemben, hiszen az Unió területén fekvő erdők szénmegkötése évi 10,9\%- ot tesz ki. Így az ágazati kibocsátások és elnyelések elszámolása kiemelkedő szerepet kap a 2021-2030 időszakban. A LULUCF rendeletben meghatározásra került az elszámolások pontos szabályai ágazatonként. Külön rendelkezik az erdőgazdálkodás, szántó, gyep, vizes területekről, és a faipari termékek elszámolhatóságának szabályairól (Országgyưlés, 2019).

Radikálisan új standard bevezetésére sürgetik az európai tudományos akadémiák az EU törvényhozóit az erőművi biomassza-felhasználáshoz kapcsolódó üvegházgázkibocsátás megfelelő elszámolása és nyilvántartása érdekében. A tudósok szerint az EU ETS jelenleg gyakorlatilag zöld utat ad az erdei biomassza kihasználásának, annak masszív éghajlati hatásai ellenére. A kérdést az EB is vizsgálja, és 2021-re az erdei biomassza energiatermelési célú felhasználására vonatkozó új fenntarthatósági kritériumokat ígér. A LULUCF rendelet 15. pontja kimondja, hogy olyan eszközrendszert kell kialakítani az országok számára, amely biztosítja a biomassza égetésével kapcsolatos kibocsátások LULUCF ágazaton belüli elszámolását. Így kerülhet csak összhangba a nemzetközileg elfogadott, az Éghajlatváltozási Kormányközi Testület (IPCC) által kiadott útmutatóval. A szervezet folyamatosan monitorozza a faalapú biomassza károsanyag-kibocsátását és külön jelentésben foglalkozott az ezzel kapcsolatos megvalósítási irányokról. Az említett jelentés előírja, hogy a faalapú biomassza égetése csak úgy valósulhat meg, hogy az nem károsítja a gazdaságot, a környezetet és a társadalmat. A Bizottság javaslata a fenntartható biomassza termelés érdekében, hogy a tüzelési célú faalapú biomassza termelésre határértéket határozzanak meg, valamint az ezeket felhasználó létesítmények számára ÜHG kibocsátás megtakarítási minimum százalékot írjanak elő. (IPCC, 2018)

A Visegrádi Négyek környezetpolitikáját nagymértékben befolyásolja az EU irányelvek és az EU rendeletek alakulása. A tagországok mindegyike próbál megfelelni az EU által elő́rtaknak, így a szakpolitikai intézkedéseket folyamatosan felülvizsgálják és alakítják. A 2004-es csatlakozás óta jelentős jogszabályi átalakuláson ment át mindegyik tagország a környezetvédelem tekintetében is, amelynek alapját képezte az EU intézkedések sorozata. A V4-s országok környezetpolitika intézmény rendszere az EU tag- 
országokéhoz hasonlóan alakul. Magyarország kivételével mindegyik ország környezetvédelmi minisztériumot működtet és a szakpolitikai feladatokat horizontális és vertikális kapcsolatok segítségével valósítják meg. Magyarország a környezetvédelmi feladatokat a minisztériumok között megosztva látja el. Az országok szakpolitikájával és a kapcsolódó feladatok részletes kidolgozásával a Nemzetei Alkalmazkodási Stratégia részletesen foglalkozik. A végleges NECP tervek elkészítése és azok végrehajtása ezen intézményrendszerek keretei között fog megvalósulni. Az EB általi elvégzett klímaterv értékelés és a kapcsolódó iránymutatások alapján az országoknak lehetőségük van módosítani az előzetes tervüket (ez szolgált alapul a jelen tanulmány elkészítéséhez is) és növelni a részvételi arányukat. Az Unió 2030. céljának elérése érdekében folyamatos NECP felülvizsgálatokat irányoz elő, amely további támogatást nyújt a tagországok számára, emellett további ösztönzők kialakítására törekszik. Elsődleges szempont, hogy az országok úgy tudják megvalósítani a vállalásaikat, hogy közben a gazdasági fejlődés is biztosított legyen számukra.

Az 1. táblázat segítségével jellemezzük a Visegrádi Csoport országainak NECP terveinek fontosabb pontjait, majd az összehasonlítást és értékelést mutatjuk be, különös tekintettel a LULUCF szektor vonatkozásaira.

\section{1. táblázat}

NECP összefoglaló táblázat

\begin{tabular}{|c|c|c|c|c|c|c|}
\hline & $\begin{array}{l}\text { Nemzeti célok } \\
\text { és hozzájárulá- } \\
\text { sok }\end{array}$ & $\begin{array}{l}\text { Az üvegházha- } \\
\text { tást okozó gázok } \\
\text { kibocsátásának } \\
\text { kötelező célja } \\
(\%)\end{array}$ & $\begin{array}{l}\text { Nemzeti cél/ } \\
\text { hozzájárulás a } \\
\text { megújuló } \\
\text { energiához } \\
(\%)\end{array}$ & $\begin{array}{l}\text { Elsődle- } \\
\text { ges ener- } \\
\text { giafo- } \\
\text { gyasztás } \\
\text { (Mtoe) }\end{array}$ & $\begin{array}{l}\text { Végső ener- } \\
\text { giafogyasz- } \\
\text { tás (Mtoe) }\end{array}$ & $\begin{array}{l}\text { A villamos- } \\
\text { energia-össze- } \\
\text { kapcsolhatóság } \\
\text { szintje (\%) }\end{array}$ \\
\hline \multirow{4}{*}{ 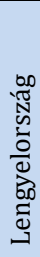 } & $\begin{array}{l}\text { Legfrissebb } \\
\text { adat }\end{array}$ & 21 & 11,30 & 100,9 & 71,8 & 4 \\
\hline & 2020 & 14 & 15 & 96,4 & 71,6 & 4 \\
\hline & 2030 & -7 & $21-23$ & 91,3 & 67,1 & 8,70 \\
\hline & $\begin{array}{l}\text { A } 2030 \text {-as } \\
\text { ambíciós szint } \\
\text { értékelése }\end{array}$ & az ESR szerint & $\begin{array}{l}\text { Csekély (25\% } \\
\text { a RES képlet } \\
\text { eredménye) }\end{array}$ & Szerény & Szerény & Nincs adat \\
\hline \multirow{4}{*}{ 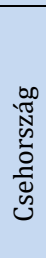 } & 2019 & 4 & 14,80 & 40,1 & 25,5 & 19 \\
\hline & 2020 & 9 & 13 & 44,3 & 25,3 & 23 \\
\hline & 2030 & -14 & 20,80 & 41,3 & 23,7 & $>15$ \\
\hline & $\begin{array}{l}\text { A } 2030 \text {-as } \\
\text { ambíciós szint } \\
\text { értékelése }\end{array}$ & $\begin{array}{l}\text { Mint az ESR-ben. } \\
\text { Üvegházhatást } \\
\text { okozó gáz } 2030 \text { - } \\
\text { 30\% 2005-ig }\end{array}$ & $\begin{array}{l}\text { Csekély (23\% } \\
\text { alatt RES kép- } \\
\text { let eredmé- } \\
\text { nye) }\end{array}$ & Alacsony & Szerény & Nincs adat \\
\hline
\end{tabular}




\section{1. táblázat folytatása}

\begin{tabular}{|c|c|c|c|c|c|c|}
\hline & $\begin{array}{l}\text { Nemzeti célok } \\
\text { és hozzájárulá- } \\
\text { sok }\end{array}$ & $\begin{array}{l}\text { Az üvegházha- } \\
\text { tást okozó gázok } \\
\text { kibocsátásának } \\
\text { kötelező célja } \\
(\%)\end{array}$ & $\begin{array}{l}\text { Nemzeti cél/ } \\
\text { hozzájárulás a } \\
\text { megújuló } \\
\text { energiához } \\
(\%)\end{array}$ & $\begin{array}{l}\text { Elsődle- } \\
\text { ges ener- } \\
\text { giafo- } \\
\text { gyasztás } \\
\text { (Mtoe) }\end{array}$ & $\begin{array}{l}\text { Végső ener- } \\
\text { giafogyasz- } \\
\text { tás (Mtoe) }\end{array}$ & $\begin{array}{l}\text { A villamos- } \\
\text { energia-össze- } \\
\text { kapcsolhatóság } \\
\text { szintje (\%) }\end{array}$ \\
\hline \multirow{4}{*}{ 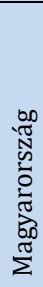 } & $\begin{array}{l}\text { Legfrissebb } \\
\text { adat }\end{array}$ & -10 & 12,5 & 24,5 & 18,5 & 50 \\
\hline & 2020 & 10 & 13 & 24,1 & 14,4 & 55 \\
\hline & 2030 & -7 & 21 & nincs cél & $\begin{array}{l}785 \\
(18,7)\end{array}$ & 60 \\
\hline & $\begin{array}{l}\text { A } 2030 \text {-as } \\
\text { ambíciós szint } \\
\text { értékelése }\end{array}$ & Az ESR szerint & $\begin{array}{l}\text { Csekély (23\% } \\
\text { a RES képlet } \\
\text { eredménye) }\end{array}$ & $\begin{array}{l}\text { Nagyon } \\
\text { alacsony }\end{array}$ & $\begin{array}{l}\text { Nagyon } \\
\text { alacsony }\end{array}$ & Nincs adat \\
\hline \multirow[b]{4}{*}{$\begin{array}{l}\frac{\pi}{\sqrt{\pi}} \\
\frac{\pi}{2} \\
\frac{0}{N} \\
\text { n }\end{array}$} & $\begin{array}{l}\text { Legfrissebb } \\
\text { adat }\end{array}$ & -5 & 11,90 & 15,8 & 11,1 & 43 \\
\hline & 2020 & 13 & 14 & 16,4 & 9,0 & 59 \\
\hline & 2030 & -12 & 19,20 & 15,7 & 10,3 & 52 \\
\hline & $\begin{array}{l}\text { A } 2030 \text {-as } \\
\text { ambíciós szint } \\
\text { értékelése }\end{array}$ & $\begin{array}{l}\text { Ambiciózus } \\
\text { (-20\% nemzeti } \\
\text { cél) }\end{array}$ & $\begin{array}{l}\text { Csekély }(24 \% \\
\text { a RES képlet } \\
\text { eredménye) }\end{array}$ & $\begin{array}{l}\text { Alacsony } \\
\text { ambíciójú }\end{array}$ & $\begin{array}{l}\text { Alacsony } \\
\text { ambíciójú }\end{array}$ & Nincs adat \\
\hline
\end{tabular}

Forrás: (European Commission, 2019), (European Commission, 2020), (European Commission, 2020) (European Commission, 2020), alapján (Table 1 NECP summary)

\section{Lengyelország NECP értékelése}

A lengyel NECP jól kidolgozottnak tekinthető. Jól áttekinti az érintett szegmenseket és tervez az energiaunió 5 dimenziójával. Az ÜHG kibocsátás tekintetében a 2030 -ig kötelező érvényű nemzeti célkitűzése, az (EU) 2018/842 rendeletnek megfelelő éves kötelező nemzeti határértékek és az (EU) 2018/841 rendelet szerinti csökkentést vállalja (-7\%). Teljesítéséhez a közlekedés, építőipar és mezőgazdasági kibocsátás csökkentését tervezi. Lengyelország számára 10 évre (2021-2030) kompenzációs határértéket rendeltek el, amelynek összege -22,5 millió tonna $\mathrm{CO}_{2}$-egyenérték (ez a teljes maximális határ, amelyet 10 év alatt fel lehet használni).

\section{2. táblázat}

Lengyelország tervezett LULUCF szektor általi ÜHG kibocsátása, $\mathrm{Kt} \mathrm{CO}_{2}$ egyenérték

\begin{tabular}{llllll}
\hline & 2020 & 2025 & 2030 & 2035 & 2040 \\
\hline Összes ÜHG kibocsátás & 397810 & 403635 & 404739 & 370476 & 333869 \\
LULUCF & $-31777,7$ & $-27337,6$ & $-21692,9$ & $-17742,6$ & $-14021,3$ \\
$\%$ & $-7,99 \%$ & $-6,77 \%$ & $-5,36 \%$ & $-4,79 \%$ & $-4,20 \%$ \\
\hline
\end{tabular}

Forrás: (Ministry of Climate and Enviroment of Poland, 2019) alapján

(Table 2. Planned GHG emissions from the LULUCF sector in Poland) 
Ehhez tervezetten hozzájárulnak a LULUCF ágazatok, Lengyelország nem zárja ki az ESR / LULUCF rugalmassági mechanizmus alkalmazását. A 2. táblázatban látható Lengyelország LULUCF szektora általi ÜHG kibocsátás tervezett mennyisége. A negatív értékek megerősítenek minket abba, hogy a Lengyel Köztársaság jogosult igénybe venni a fent említett rugalmassági mechanizmust. A LULUCF általi szénmegkötés pedig jelentős mértékben biztosított. Várhatóan a LULUCF ágazat részesdése az összes ÜHG kibocsátásból csökkenni fog, de ezzel egyetemben az össz ÜHG kibocsátás is csökkenést mutat. Az egyes légköri szennyező anyagok nemzeti kibocsátásának csökkentéséről, a 2003/35 / EK irányelv módosításáról és a 2001/81 / EK irányelv (NEC irányelv) hatályon kívül helyezéséről szóló, 2016. december 14-i 2016/2284 irányelv arra kötelezi Lengyelországot, hogy két időszakban hajtsa végre szennyezés csökkentési céljait, nevezetesen 2020-2029 és 2030 (a 2005. referenciaévhez viszonyítva). A célkitűzések a következők:

- $59 \%$ és $70 \% \mathrm{SO}_{2}$-re,

- 30\% és $39 \% \mathrm{NO}_{\mathrm{x}}$-re,

- 25\% és 26\% NMVOC-ra,

- $1 \%$ és $17 \% \mathrm{NH}_{3}$-ra,

- $16 \%$ és $58 \% \mathrm{PM}_{2,5}$-re.

A megújuló energia hozzájárulás az ország NECP tervezetében csekély ambíciójú (21-23\%-os) hozzájárulást vállal. A RES képlet alapján azonban az Unió további vállalás növelést javasol Lengyelország számára. A tervezet nem rendelkezik pontos intézkedési tervvel, sem politikával, hogy milyen módon szeretné megvalósítani a kitűzött célokat. Viszont fontos, hogy a megújuló energia egyre nagyobb teret nyerjen az üzleti lehetőség és a munkahelyek létrehozásában. 2009. április 23-i 2009/28 / EK európai parlamenti és tanácsi irányelv arra kötelezi Lengyelországot, hogy 2020-ra a megújuló energia minimális 15\% -os arányát érje el a bruttó végső energiafogyasztásban.

Az Európai Parlament és a Tanács 2012/27 / EU irányelve (2012. október 25.) az energiahatékonyságról, a 2009/125 / EK és a 2010/30 / EU irányelv módosításáról, valamint a 2004/8 / EK és a 2006/32 / EK irányelv hatályon kívül helyezéséről, a 2018. évi felülvizsgálatával (a továbbiakban: 2012/27 / EU irányelv) módosított keretet hoz létre az energiahatékonyság javítását elősegítő intézkedések kereteihez az EU-ban annak érdekében, hogy 2020/2030ig biztosítsák az EU energiahatékonysági célkitűzését. Mindezek alapján az EU 
lehetőséget ad minden tagállam számára, hogy indikatív nemzeti energiahatékonysági célt tűzzön ki, amely primer vagy végső energiafogyasztáson, primer vagy végső energia megtakarításon vagy energiaintenzitáson alapul. Lengyelország hozzájárulása az 1. táblázatban olvasható. Az energiabiztonság megteremtése a tervezet fontos eleme. Lengyelország kész intézkedéseket és politikát állított össze a hatékony tevékenység megvalósítás érdekében. A legnagyobb megoldandó problémaként az energiafüggőség diverzifikálását határozta meg.

A belső energia piac dimenziójában a lengyel tervezet átfogó módon rendelkezik a politikával és intézkedésekkel többek között beruházásokat tervez az áramlás javítására a térségben, Németország, Csehország és Szlovákia bevonásával. A villamosenergia belső piacáról szóló (EU) 2019/943 európai parlamenti és tanácsi rendelet értelmében 2020. január 1-jétől az átviteli rendszer-üzemeltetőknek maximalizálniuk kell a határokon átnyúló kereskedelem számára kínált összekapcsolási kapacitást. Erre külön nemzeti tervet készített a lengyel kormány. Feltehetően a megtervezett intézkedések az egész Unió területére kedvező hatásokat gyakorolnak.

A Kutatás és innováció területét figyelembe véve, a politikák és intézkedések már rendelkezésre állnak. Az „Energia innovációs fejlesztési irányai” című kiadványban. 2025-re egymillió elektromos jármü használatát tervezi A NECP GDP 2,5 \%-ának megfelelő beruházási igényeket ír elő az energia termelő ágazatok számára, annak érdekében, hogy a célkitűzések megvalósulhassanak. A tervezet különféle magas szintű regionális együttműködésekre és kétoldalú kezdeményezésekre utal (Visegrádi Csoport). Lehetséges együttműködés fokozása a belső piac az átmeneti kérdések, a dekarbonizáció és a megújuló energiaforrások kiépítésének szervezésében (Ministry of Climate and Enviroment of Poland, 2019).

\section{Csehország NECP értékelése}

Az Európai Parlament és a Tanács (EU) 2018/842 rendelete Csehország számára kötelező érvényű, az előző tagországhoz képest magasabb kibocsátáscsökkentési célt határoz meg 2005-höz képest (-14\%). Az ÜHG kibocsátás csökkentése során fontos az egészségügyi kockázatok csökkentése. Ennek részeként bevonásra kerülnek a helyi termelők, vállalkozók, valamint a háztartások és épületek energiahatékonyságnak növelése. Emellett a közlekedés kibocsátásnak csökkentésére dolgoztak ki részletes terveket. A Cseh Köztársa- 
ság elkötelezettségét az ÜHG kibocsátás csökkentése érdekében az is megmutatja, hogy tanulmányokat, terveket, stratégiákat készítettek és összhangba hozták az Uniós elvárásokkal. Kész politikai és intézkedési alap áll rendelkezésükre 2020-tól 2030-ig.

\section{3. táblázat}

Csehország tervezett LULUCF ágazat ÜHG kibocsátása, $\mathrm{Kt} \mathrm{CO}_{2}$ egyenérték

\begin{tabular}{llllll}
\hline & 2020 & 2025 & 2030 & 2035 & 2040 \\
\hline Összes ÜHG kibocsátás & 125940 & 114200 & 109210 & 98390 & 92910 \\
LULUCF & 1250 & -1090 & -490 & -610 & -100 \\
$\%$ & $0,99 \%$ & $-0,95 \%$ & $-0,45 \%$ & $-0,62 \%$ & $-0,11 \%$ \\
\hline
\end{tabular}

Forrás: (Ministry of the Environment of the Czech Republic, 2019) alapján

(Table 3. Planned GHG emissions from the LULUCF sector in Czech Republic)

A Cseh Köztársaság valószínúleg nem tudja használni a rugalmasságot az (EU) 2018/842 rendelet 7. cikkével összhangban. Az erdőgazdálkodás szerepe megváltozik az elkövetkezendő években. A kéregbogár katasztrófa következtében a fakitermelés jelentősen megnövekedett az elmúlt években. A kezelt erdőterületek ÜHG kibocsátása nem tudja megvalósítani a nullszaldós kibocsátás követelményét. A 3. táblázatban láthatjuk, hogy a LULUCF ágazat ÜHG kibocsátása pozitív értéket vesz fel 2020-ban, valamint a későbbiekben is csak csekély mértékben billen át a negatív irányba. A LULUCF ágazat részesedése az össz ÜHG kibocsátásból Csehország esetében meglehetősen gyengébben alakul, mint Lengyelország tekintetében. A fent említett ok, valamint az új erdő telepítések következtében.

Csehország a megújuló energiaforrások növeléséhez hasonló arányt biztosít, mint Lengyelország. Csehország vállalja, hogy az energiaunió irányításáról és az éghajlatváltozásról szóló (EU) 2018/1999 rendelet 4. cikkének (2) bekezdése alapján 2022-ig 14,62\% -os részesedést ér el, és 2025-ig 16,87\% -ot, majd 18,85\% -ot 2027-ig. RES képlet által számított érték esetében azonban Csehország esetében magasabb arány növekedést várnak el.

Energiahatékonyság és biztonság tekintetében a 2012/27 EU irányelv 3. cikkében meghatározottak szerint, Csehország célként a végső energia megtakarítást 84 PJ-t illetve 464 PJ kumulált értékben határozza meg, amely megfelel az évenkénti minimális 0,8\%-os energia-megtakarítás követelményének. Az energia biztonság tekintetében átfogó politikai és intézkedési kereteket hatá- 
roztak meg, valamint az importenergia-függőség csökkentésében látják a megoldást. 2030-ig 65\%-kal tervezik csökkenteni az energia függőséget, majd további -5\%-os csökkentést tervnek 2040-ig. Látható, hogy Lengyelországhoz hasonlóan nagyobb hangsúlyt fektetett Csehország is az energiabiztonság dimenziójára.

A belső energia piac dimenziójának vizsgálata alapján elmondható, hogy általánosságban megfelel a cseh állam a 15\%-os célnak, mivel maximális terhelés alatt a beépített kapacitások 50\%-a áll. Így az ország a saját belsőenergia piacának fejlesztésére koncentrál.

Innováció és kutatás területen Csehország nem határozott meg külön $\mathrm{K}+\mathrm{F}$ intézkedéseket. Más állami támogatású kutatási és innovációs tevékenységeket, kiadványokat, stratégiákat viszont megnevezett, amely az ország energia és éghajlat-politikáját segíti elő (Ministry of the Environment of the Czech Republic, 2019).

\section{Magyarország NECP értékelése}

ÜHG kibocsátás tekintetében Magyarország az Európai Parlament és a Tanács (EU) 2018/842 rendelete alapján 2021-2030 közötti időszakra a kötelező kibocsátás csökkentést vállalja (-7\%), amelyben érvényesíteni kívánja az ESR rendeletet. A cél megvalósítását az atomerőművek fejlesztésével, a lakossági fütésrendszerek átalakításával, a közlekedés zöldítésével, a mezőgazdaság támogatásával (HMKÁ), valamint a hulladékgazdálkodás fejlesztésével és - a Nemzeti Erdőstratégiával összhangban - a szénmegkötés elősegítésével tervezi.

A 4. táblázatban láthatjuk, hogy az időszakban várhatóan folyamatosan csökkeni fog a LULUCF ágazat általi elnyelés. Hasonlóan Lengyelországhoz, bár volumenbeli eltérések az országok között jelentősek. Mind az össz ÜHG kibocsátás mind a LULUCF ágazat általi kibocsátások tekintetében. A LULUCF ágazat kibocsátásának részesedése az össz ÜHg kibocsátásból 5\% körülire prognosztizálható. Magyarország esetében az össz ÜHG kibocsátás mértéke jelentősebb mértékű csökkenés figyelhető meg mint ez előző országok esetében.

\section{4. táblázat}

Magyarország tervezett LULUCF ágazati ÜHG kibocsátása, $\mathrm{Kt} \mathrm{CO}_{2}$ egyenérték

\begin{tabular}{llllll}
\hline & 2021 & 2022 & 2025 & 2027 & 2030 \\
\hline Összes ÜHG kibocsátás & 63210 & 61945 & 55131,762 & 51823,85628 & 49750,902 \\
LULUCF & $-3120,377$ & $-3002,615$ & $-2811,168$ & $-2653,964$ & $-2327,608$ \\
$\%$ & $-4,94 \%$ & $-4,85 \%$ & $-5,10 \%$ & $-5,12 \%$ & $-4,68 \%$ \\
\hline
\end{tabular}

Forrás: (Innovációs és Technológiai Minisztérium, 2019) alapján

(Table 4. Planned GHG emissions from the LULUCF sector in Hungary) 
Megújuló energia dimenziójának esetében Magyarország a bruttó végső energiafogyasztásban legalább az 1. táblázatban említett megújuló energiaforrás részarányt tűzte ki célul. Megvalósítása a hűtés-fütés rendszer megújuló energia arányának növelése (2030-ra 30\%) és a közlekedés részarányának növelésében (2030-ra 14\%) rejlik. Magyarország a bruttó végső villamosenergiafogyasztásban a megújuló források arányát 2030-ra legalább 20\%-ra kívánja növelni. Magyarország tekintetében a megújuló energia dimenziója jelentősebb hangsúlyt kap, mint a többi tagország esetében. Ezt a tervezett részarányok növekedése volumene támasztja alá. Azonban a RES képlet eredménye alapján az országnak még ennél is jelentősebb mértékben kellene növelni a megújuló energia részarány az összenergia-felhasználásból.

Energiahatékonysági célkitűzése a magyar államnak, hogy az ország végső energia-felhasználása 2030-ban se haladja meg a 2005-ös értéket (785 PJ). A végső energiafelhasználás 2005-ös szintet meghaladó növekedése esetén a növekmény kizárólag karbonsemleges energiaforrásból származhat. A hozzájárulás mértéke meglehetősen alacsony, amelyet a gazdasági helyzet alakulására hivatkozva vállalt az ország. Fontos, hogy a vállalás úgy valósuljon meg, hogy közben a gazdasági folyamatok ne sérüljenek. Kiemelkedően fontosnak tartják, hogy a GDP növekedésének az üteme nagyobb mértékű legyen, mint az energiafelhasználás növekedésének üteme. A kitűzött cél érdekében külön stratégiát és politikai alapokat hoztak létre. A klíma terv alapján jól látszik, hogy Magyarország jelentős hangsúlyt fordít erre a dimenzióra is.

Energiabiztonság dimenziója esetében Magyarország tervében kitér arra, hogy a legfontosabb cél az, hogy az energiafüggetlenségét erősítse, a következő eszközök segítségével: az energiahatékonyság növelése, megújuló energiaforrások fenntarthatóságának maximalizálása, nukleáris kapacitások biztonságos szinten való tartása. Ezzel az importfüggőség csökkenését, a piaci integráció erősítését és a diverzifikált ellátási lánc kialakítását kívánja elérni. Az energiabiztonság dimenziójában Magyarország tervében visszautal az előző két dimenzió fontosságára. Megállapítható, hogy az állam számára ezen dimenziók fejlesztésén van a legnagyobb hangsúly, hasonlóan ez előzőekben vizsgált tagországokhoz.

Belső energiapiac keretében a villamosenergia-rendszer összeköttetésre vonatkozó EU-s célszámot Magyarország már most is jelentősen meghaladja. Ennek ellenére a rendszer összeköttetések arányát 2030-ra növelni szeretné. 
A kitűzött cél megvalósításához piaci integráció erősítésére van szükség. Ezen túlmenően, az ezzel kapcsolatos projektek előmozdítása szükséges.

Magyarország $\mathrm{K}+\mathrm{F}+\mathrm{I}$ dimenzió esetében több stratégiát és tervet készített el, valamint további tervek készítését vetítette előre. Hiszen a klímaváltozás ellen hatékonyan csak folyamatos kutatások mellett lehet fellépni. Az ezzel foglalkozó ágakat kívánja jelentős mértékben támogatni, ösztönözni. Magyarország célja, hogy 2030-ig legalább 20 kísérleti innovációs projektet hajtson végre, amelyek megvalósítása során legalább 10 szabadalom jöjjön létre (Innovációs és Technológiai Minisztérium, 2019).

\section{Szlovákia NECP értékelése}

Dekarbonizáció megvalósítása érdekében Szlovákia igénybe szeretné venni az ESR rendeletet, így az Európai Parlament és a Tanács (EU) 2018/841 rendelete (2018. május 30.) által kiszabott kötelezőség mértékét vállalja (1. táblázat). Az üvegházhatást okozó gázok kibocsátásának és a földhasználatból, a földhasználat megváltoztatásából és az erdőgazdálkodásból származó 2030-as éghajlat- és energiaügyi keretbe történő felvételéről, valamint a (Az 525/2013 / EU és az 529/2013 / EU határozatot 2018-ban fogadták el. A 2014-ben elkészítette és 2018-ban felülvizsgált NAS program részletesen rendelkezik a megvalósításról, amelyet a Szlovák Köztársaság kormányának 478/2018. Sz. határozata hagyta jóvá.

A LULUCF szektor tekintetében az előre jelzések szerint a $\mathrm{CO}_{2}$ megkötése a 4 600-9 $000 \mathrm{Gg} \mathrm{CO}_{2}$ tartományba fog esni. Az 5. táblázat megmutatja, hogy tervezetten Szlovákia LULUCF ágazati ÜHG kibocsátása tartósan és mélyen negatív értékeket mutat. Így az előzőekben említett $\mathrm{CO}_{2}$ megkötési tervezet megvalósulása alátámasztásra került. Láthatjuk Szlovákia esetében, az össz ÜHG kibocsátás volumene sokkal alacsonyabb, mint az előzőekben vizsgált országok esetében. A LULUCF ágazat általi kibocsátások, pedig magasabb értékeket vesz fel mint Magyarország vagy Csehország. Az 5. táblázat utolsó sora alapján elmondható, hogy Szlovákia LULUCF ágazatainak részesedése az össz ÜHG kibocsátásból kétszer annyi, mint Magyarország és Lengyelország tekintetében, valamint több min tízszerese Csehország esetében megfigyelt részesedésének. Szlovákia szerencsés helyezte a földrajzi adottságainak köszönhető. Az ÜHG kibocsátás alacsonyabb értékét pedig befolyásolja a gazdaságban megjelenő ÜHG igényes ágazatok alacsonyabb részaránya az előző országokhoz képest. 


\section{5. táblázat}

Szlovákia tervezett LULUCF ágazati ÜHG kibocsátása, $\mathrm{Kt} \mathrm{CO}_{2}$ egyenérték

\begin{tabular}{llll|ll}
\hline & 2020 & 2025 & 2030 & 2035 & 2040 \\
\hline Összes ÜHG kibocsátás & 42355 & 42046 & 41399 & 39526 & 38521 \\
LULUCF & $-6145,05$ & $-5040,44$ & $-4434,01$ & $-4155,84$ & $-4231,16$ \\
$\%$ & $-14,51 \%$ & $-11,99 \%$ & $-10,71 \%$ & $-10,51 \%$ & $-10,98 \%$ \\
\hline
\end{tabular}

Forrás: (Slovak Ministry of Economy, 2019) alapján

(Table 5. Planned GHG emissions from the LULUCF sector in Slovakia)

Megújuló energia tekintetében a Szlovák Köztársaság 2030 -ra vállalt részarány, 5,2 százalékpontos növekedést jelent a 2020-ra kitűzött célhoz képest. A rendelet 4. cikkének (2) bekezdésében foglalt követelmények alapján a 2022, 2025 és 2027 14,94\%, 16,24\% és 17,38\% a cél. A megújuló energiaforrásokkal kapcsolatos célkitűzések megvalósításához szükséges teljes beruházási költségeket 4,3 milliárd euróra becsülik. Ezek a beruházási költségek magukban foglalják a villamos energia- és fütési ágazat költségeit is. A tervezett lépések hasonlóan alakulnak, mint ahogy Magyarország esetében már megfigyelhettük. A RES képlet eredménye alapján azonban további vállalás növelést javasol az EB.

Energiahatékonyság esetében a Szlovák Köztársaság hozzájárulása csekélynek mondható. Viszont két lehetséges forgatókönyvet hozott létre, így elhivatottság látszik a témával kapcsolatosan. E forgatókönyvek kidolgozásakor a kiindulópont az alacsony szén-dioxid-kibocsátású növekedési tanulmány volt. A kidolgozott forgatókönyvekben ipari technológiák fejlesztését a közlekedés innovációját, atom -és villamos energia átalakulását nevezte meg főbb mechanizmusoknak a dimenzió kielégítéséért.

Energia biztonság a Szlovák Köztársaságban az áramellátás biztonságának megőrzésével kapcsolatos kötelezettségeket és felelősségeket a 251/2012. Sz. Törvény (az energiáról szóló törvény, valamint néhány más törvény módosításáról és kiegészítéséről) határozza meg. Ezen felül intézményi és politikai felkészültséggel rendelkezik az ország a dimenzió biztosítása érdekében. Kitér arra, hogy az energiafüggőség csökkentésében rejlik az energia biztonság megteremtése. Összevetve a többi tagországgal látható, hogy a V4-ek tekintetében ebben a dimenzióban a legnagyobb problémakör az energiafüggősség és annak csökkentésének lehetőségei. 
Belső energia piac kialakítása érdekében a Szlovák Köztársaság 2017-ben is magas átviteli rendszer-összekapcsolási szintet ért el, valamint a tanulmányok szerint várhatóan tovább fog növekedni 2030-ra. Szlovákia így teljesíti az Unió által elvárt követelményeket a Bizottság 2017. novemberi jelentése szerint, amely rendelkezik az összekapcsolások minimum százalékáról. A TYNDP 2018. elemzése szerint a Szlovák Köztársaság az első két kritériumban az öszszes megfontolt forgatókönyv esetében $60 \%$ feletti összekapcsolási szintet ér el. Azaz a feltételezett maximális terhelés 230-250\% -án termikus importkapacitást és termikus export kapacitást vetít előre a tervezett telepített megújuló energiatermelés 160-282\% -ának szintjén.

Szlovákia évente $\mathrm{K}+\mathrm{F}$ elemzést végez az OECD-el együttműködve. A releváns információk terjesztésével több intézmény lett megbízva, arra átfogó rendszer lett kiépítve. Ezáltal naprakész jelentések állnak rendelkezésre a döntéshozók számára a források alakulásáról és a projektről. Pontos tervezetekben rendelkeznek a források alakításáról és az érintett területekről 20202024 -es időszakra, kitekintéssel 2029-re (Slovak Ministry of Economy, 2019).

\section{KÖVETKEZTETÉSEK}

A V4-ek vállalásai megfelelnek az EU elvárásainak, azonban ambíciójuk mind az 5 dimenzió területén alacsony. A V4-ek közül három tagország jogosult igénybe venni az ESR rendelet mechanizmusát, amely lehetőséget ad a LULUCF ágazatban tervezett ÜHG elnyelési értékeinek bizonyos mértékű érvényesítésére. Ezeket figyelembe véve az országok az EU által elvárt minimum szintű csökkentést vállalták az ÜHG tekintetében. A többi dimenzió esetében is törekedtek az országok a minimum követelmények szintjén maradni. A megújuló energia dimenziójának tekintetében, minden ország esetében a RES képlet alapján elmondható, hogy a vállalások növelése szükséges. Az energiahatékonyság terén egyedül Lengyelország esetében, figyelhettük meg, hogy a szerény (5\%) hozzájárulási ambícióval rendelkezik. Csehország és Szlovákia esetében alacsony (0-5\%), míg Magyarország esetében pedig nagyon alacsony (0\% alatti) hozzájárulási ambíciót láthattunk. Az energiahatékonyság alacsony hozzájárulás mértékét a COVID-19 járvány által bekövetkezett gazdasági veszteségre hivatkozva állították be a tagországok. Energiabiztonság tekintetében az import függőség legyőzése a legfontosabb mindegyik ország számára. Ennek elérése érdekében az országcsoporton belüli együttműködésnek jelentős szerepe lehet a következő időszakban az együttműködések növelésével. A belső energiapiac dimenziójánál az összekapcsolások tervezésének tekinteté- 
ben a hozzájárulási hajlandóság meglehetősen alacsony. Hiszen mindegyik ország esetében a belső energia piaci összekötetések elérik az Unió által előírt értékeket. Az összekapcsolhatóságot ugyan növelni fogják az országok, de nem túl jelentős mértékben. $\mathrm{K}+\mathrm{F}+\mathrm{I}$ esetében pedig sajátos módon rendelkeznek a következő időszakra vonatkozó terveikről. Amelyek leginkább az országok egyes igényeik kielégítésre szolgálnak.

A tagországok vállalásainak különbségét az eltérő nemzetgazdasági felépülés, valamint az eltérő földrajzi viszonyok okozhatják. Az országok közötti különbségek értékelés során nem hagyható figyelmen kívül húzóágazatok közötti jelentős differenciáltság sem. Az országok elkötelezettségét nagymértékben befolyásolja a nagy energiaigényű és a jelentős ÜHG kibocsátású ágazatok aránya a nemzetgazdaságon belül. Leginkább Lengyelország és Csehország tekintetében jelent ez problémát a nehézipar és a szénalapú energiatermelés miatt. Szlovákia és Magyarország esetében ez kevésbé érvényesül, illetve ezen országok esetében a földrajzi adottságok kedvezőbben alakulnak, mint az előző két ország esetében. Az utóbbi országok tekintetében a LULUCF ágaztok általi elnyelések kedvezőbben alakulhatnak, mint az előzőek esetében. Összességében elmondható, hogy a tagországok mindegyike számára nagy kihívásokat rejteget a következő időszak célkitűzéseinek megvalósítása. A visegrádi együttműködés erősítése azonban segítséget és támogatást nyújthat a tagországok számára.

Az áttekintett környezetvédelmi politikai szegmens rámutat arra, hogy miért is fontos szigorú szabályozások közé kötni a környezetvédelmet. A tervek értékelése során megmutatkozott melyik ország milyen mértékben hajlandó hozzájárulni az EU 2030-as céljához, illetve milyen lépéseket kíván megtenni. A vizsgálataink alapján jól látható, hogy a NECP kidolgozottságok és vállalások jelentősen eltérnek egymástól, valamint az országok készültségi szintje is különböző. A részvételi hajlandóságot nem csak az államok egyéni vállalásai, hanem az EU által előírt kötelezőségek is alakítják. Kiemelésre kerültek a LULUCF ágazatok által tervezett ÜHG kibocsátás/elnyelés szintek, valamint bemutatásra került az ETS rendszerében és azon kívül eső ágazatok hozzájárulása a kibocsátás csökkentéshez. A LULUCF, mint ETS-en kívül eső ágazat hozzájárulása jelentős, de a fakitermelés valamint a hozzákapcsolódó biomassza égetéssel kapcsolatos légszennyező kibocsátások elszámolása tekintetében még az intézkedések hiányosak, felülvizsgálatuk szükséges az Európai Parlament részéről. 
Köszönetnyilvánítás: A publikáció elkészítését az EFOP-3.6.3-VEKOP-16-201700008 számú projekt támogatta. A projekt az Európai Unió támogatásával, az Európai Szociális Alap társfinanszírozásával valósult meg.

AZ INNOVÁCIÓS ÉS TECHNOLÓGIAI MINISZTÉRIUM ÚNKP-20-2 KÓDSZÁMÚ ÚJ NEMZETI KIVÁLÓSÁG PROGRAMJÁNAK A NEMZETI KUTATÁSI, FEJLESZTÉSI ÉS INNOVÁCIÓS ALAPBÓL FINANSZÍROZOTT SZAKMAI TÁMOGATÁSÁVAL KÉSZÜLT és AZ INNOVÁCIÓS ÉS TECHNOLÓGIAI MINISZTÉRIUM ÚNKP-20-3-II KÓDSZÁMÚ ÚJ NEMZETI KIVÁLÓSÁG PROGRAMJÁNAK A NEMZETI KUTATÁSI, FEJLESZTÉSI ÉS INNOVÁCIÓS ALAPBÓL FINANSZÍROZOTT SZAKMAI TÁMOGATÁSÁVAL KÉSZÜLT.

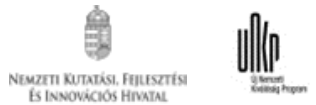

\section{IRODALOMJEGYZÉK}

Az Európai Unió Működéséről szóló Szerződés Egységes Szerkezetbe Foglalt Változata. (2012.). Az Európai Unió Hivatalos Lapja, 132-133.

Európai Bizottság. (2019). Az euróapai zöld megállapodás COM (2019) 640 final. Forrás: Link

Európai, B. (2014). Közérthetően az Európai Unió szakpolitikáiról. Forrás: Link (letölve 2021.06.11)

European Commission. (2019). United in delivering the Energy Union and Climate Action - Setting the foundations fora successful clean energy transition SWD (2019) 212 fina. Forrás: Link

European Commission. (2019). Assessment of the draft National Energy and Climate Plan of Czechia., (old.: 4-5). Brüsszel.

European Commission. (2020). Assessment of the final national energy and climate plan of Hungary., (old.: 4). Brüsszel.

European Commission. (2020). Assessment of the final national energy and climate plan of Poland., (old.: 4). Brüsszel.

European Commission. (2020). Assessment of the final national energy and climate plan of Slovakia. Brüsszel.

EUROSTAT., D. (2021). Forrás: Link (utolsó letöltés: 2021.02.11)

Innovációs és Technológiai Minisztérium. (2019). Nemzeti Energia-és Klímaterv., (old.: 19,45-46).

IPCC. (2018). A megújuló energia a fenntarható vidékfejlesztés szolgálatában: jelentős poptenciális szinergiák, amelyek azonban nagyrészt kiaknázatlanok. Luxemburg : Európai Számvevőszék 29-34.

Ministry of Climate and Enviroment of Poland. (2019). The National Energy and Climate Plan for 20212030, Objectives and targets, and policies and measures., (old.: 22-39).

Ministry of the Environment of the Czech Republic. (2019). National Energy and Climate Plan of the Czech Republic., (old.: 3,27-29).

Országgyűlés Hivatala. (2020). Európai Zöld Megállapodás. Infojegyzet, 2020/58 szám, 2.

Országgyűlés, H. (2019). Az Európai Unió kibocsátási-kereskedelmi rendszere. Infojegyzet, 1-3.

Slovak Ministry of Economy. (2019). Integrated National Energy and Climate Plan for 2021 to 2030., (old.: 7-11,39-43).

Szepesi, A. (2015). Az erdőgazdálkodás szabályozása az EU klímapolitikai céljainak elérése érdekében. NAIK ERTI szemináriumi előadás, Sárvár, Vas (3-10 ppt). Link (letöltve 2021 02.12)

(C) Copyright 2021 by the authors. This is an open access article under the terms and conditions of the Creative Commons attribution (CC-BY-NC-ND) license 4.0. 